\title{
SIMBOLOGÍA TOPOGRÁFICA EN LOS RELATOS FANTÁS- TICOS DE AMBROSE BIERCE: EL BARRANCO
}

\author{
Sonia SANTOS VILA \\ Universidad de Valladolid
}

\begin{abstract}
Whether in camp or on the march, in barracks, in tents, or en bivouac, my duties as topographical engineer kept me working like a beaver -all day in the saddle and half a night at my drawing-table, platting my surveys. It was hazardous work; the nearer to my enemy's lines I could penetrate, the more valuable were my field notes and the resulting maps. It was a business in which the lives of men counted as nothing against the chance of defining a road or sketching a bridge. Whole squadrons of cavalry escort had sometimes to be sent thundering against a powerful infantry outpost in order that the brief time between the charge and the inevitable retreat might be utilized in sounding a ford or determining the point of intersection of two roads. (...) Our frequent engagements with the Confederate outposts (...) fixed in my memory a vivid and apparently imperishable picture of the locality - a picture serving instead of accurate field notes, which, indeed, it was not always convenient to take ... 1
\end{abstract}

El texto anterior proviene de la primera narración de guerra de Ambrose Bierce, publicada en Wasp, el 29 de septiembre de 1883, y titulada "George Thurston. Three Incidents in the Life of a Man". Esas palabras del narrador en primera persona que describe con extraordinaria precisión el oficio del ingeniero topógrafo bien pueden ser atribuidas al propio Bierce, narrador testigo de su propio relato, acostumbrado al diseño de notas de campo y mapas especialmente durante el período de la Guerra de Secesión norteamericana.

Ambrose Bierce era un hombre polifacético: a lo largo de su vida desempeñó diversas profesiones como las de camarero, ayudante de imprenta, soldado (en donde se incluyen varios ascensos dentro de la carrera militar), topógrafo, periodista, escritor y crítico. Nuestra atención en esta exposición se dirige a la imbricación de dos de esas profesiones: el topógrafo y el escritor de relatos breves. Las narraciones de Bierce rebosan de una exquisitez y detallismo paisajístico extraordinarios. En ellas son elementos recurrentes una serie de accidentes geográficos que permiten pensar en la atribución de un significado oculto por parte del escritor a los citados elementos, a pesar de una envolvente y constatada atmósfera realista. Uno de esos elementos recurrentes es el barranco o el abismo.

Nuestro estudio se divide en dos secciones. En un primer apartado damos cuenta de los antecedentes biográficos del autor que permiten explicar ese inte-

\footnotetext{
${ }^{1}$ Véase Bierce, A., "George Thurston. Three Incidents in the Life of a Man", en Hopkins, E. J. (comp.), The Complete Short Stories of Ambrose Bierce, Lincoln and London, University of Nebraska Press, 1984, p.369. De ahora en adelante esta edición servirá como marco de referencia textual, de tal modo que cualquier cita de los relatos de Ambrose Bierce se designará con el número de página correspondiente a la mencionada edición.
} 
rés por transplantar sus inquietudes topográficas a las propiamenteliterarias. La segunda sección analiza el uso reiterado del barranco, concretamente, en los re latos fantásticos de A mbrose Bierce, así como el significado que se desprende de esa recurrencia.

\section{A mbrose Bierce como topógrafo.}

David Bosse ${ }^{2}$ nos informa de que la introducción de Bierce en la topografía militar se produjo en el año 1859 en el Kentucky Military Institute en Franklin Springs, donde el autor, un adolescente de diecisiete años, había sido enviado por su tío, el abolicionista Lucius Verus Bierce. Esa institución ofrecía instrucción en planimetría con brújula solar, planimetría geodésica con proyecciones esféricas, cartografía y topografía. No existen documentos en torno al trabajo escolar de Bierce, pero es muy probable que allí aprendiera las bases para lo que desarrollaría años más tarde.

Existen dos cuadernos topográficos de su servicio en la Guerra Civil. Uno retrata la campaña de Atlanta de 1864 y subsecuentes campañas en Tennessee. El otro está compuesto por notas extraídas de una exploración topográfica del área entre Atlanta y East Point (Georgia). Carey McWilliams, en su biografía sobre Bierce, destaca el mapa topográfico de la batalla de Brown's Ferry (Tennessee) en noviembre de 1863 por su elaboración3. Otras cartas como las de las condiciones del suelo en Pickett's Mill y la posición de la brigada del general Hazen en Resaca son muestras notables de su maestría topográfica.

La guerra finalizó para el autor en 1865. En 1866 el general Hazen solicitó la presencia del lugarteniente Bierce en un viaje de inspección de avanzadas occidentales. El soldado aceptó y completó otro cuaderno retratando la trayectoria desde Fort Laramie, en el territorio de Dakota, hasta Fort Benton, en el territorio de Montana, entre el 16 de agosto y el 20 de septiembre. Cuando el viaje finalizó, se ordenó a Hazen y Bierce que fueran a Washington vía San Francisco y Panamá. Bierce pensaba que su inmediato ascenso sería el de capitán en el ejército regular; sin embargo, en San Francisco descubrió que su graduación era sólo la de segundo lugarteniente. Así pues, dejó a Hazen y se quedó en California comenzando su labor de periodista.

En 1877 A. L. Bancroft and Company de San Francisco publicaron Map of the Black Hills Region, Showing: the Gold Mining District and the Seat of the Indian War, Drawn by A. G. Bierce. Era uno de los cientos de mapas que aparecieron como respuesta a la fiebre del oro americana en la segunda mitad del siglo XIX. A

${ }^{2}$ Véase Bosse, D., "From Maps to the Macabre: Ambrose Bierce as Topographer", Geography and Map Division Bulletin, SLA. 144, June, 1986, pp.2-15. David Bosse es conservador de mapas en la Biblioteca William S. Clemens en la Universidad de Michigan, Ann Arbor.

${ }^{3}$ Véase McWilliams, C., Ambrose Bierce. A Biography, Archon Books, 1967, p.52. McWilliams señala que sus dos cuadernos de guerra son nítidos, precisos y ordenados, muy acordes con la personalidad del propio autor. Añade que Bierce podía dibujar y bosquejar con extraordinaria destreza y su caligrafía era modelo de claridad y exactitud. Sus ciencias favoritas eran la Astronomía, la Lógica y la Ingeniería. 
pesar de que estaba personalmente familiarizado con la región, no fue hasta 1880 cuando penetró físicamente en las Black Hills. Pretendía dirigir la Black Hills Placer Mining Company junto con otro socio. La experiencia fue un desastre, pero el tiempo no había disminuido sus habilidades como topógrafo. No obstante, el mapa de la región de las Black Hills fue el último documento conocido desu destreza cartográfica.

El gusto de Ambrose Bierce por los accidentes geográficos no sólo se desprende de su actividad topográfica. Sus cartas revelan el placer que experimentaba en sus excursiones a través de cañones y barrancos. El 12 de septiembre de 1903 escribe a su amigo, el poeta George Sterling, desde Aurora (West Virginia), y le comenta lo siguiente: My friends have returned to Washington, and I'm having great times climbing peaks (they are knobs) and exploring gulches and cañons -for which these people have no names- poor things4.

El 11 de noviembre de 1910 envía a su sobrina Lora una carta desde Washington, D. C., en la que le confiesa su deseo de ser enterrado en el Gran Cañón. Tres días más tarde vuelve a escribirle y el contenido de la carta se circunscribe a la admiración del escritor por ese lugar apreciado para su enterramiento: Dear Lora, You asked me about the relative interest of Yosemite and the Grand Cañon. It is not easy to compare them, they are so different. In Yosemite only the magnitudes are unfamiliar; in the Cañon nothing is familiar -at least, nothing would be familiar to you, though I have seen something like it on the upper Yellowstone. The "color scheme" is astounding -almost incredible, as is the "architecture". As to the magnitudes, Yosemite is nowhere. From points on the rim of the Cañon you can see fifty, maybe a hundred, miles of it. And it is never twice alike. Nobody can describe it. Of course you must see it sometime $(. . .)^{5}$.

Es un hecho evidente el conocimiento del terreno por Bierce derivado de su formación topográfica y de su consecuente puesta en práctica durante el período de la Guerra Civil norteamericana. Es un hecho evidente también el gozo que le supone la contemplación del diseño de la tierra. El segundo punto trata de cómo sus relatos fantásticos (y no sólo sus cartas) se hacen eco de ese conocimiento y de ese gozo.

\section{La simbología del barranco en los relatos fantásticos de Ambrose Bier-}

ce.

El corpus simbólico de Ambrose Bierce en sus relatos (en particular, Ios fantásticos) es rico y variado6. Entre su simbología del paisaje natural hay un

\footnotetext{
${ }^{4}$ Véase Pope, B. C. (ed.), The Letters of Ambrose Bierce, New York, Gordian Press, 1967, p.75.

${ }^{5}$ Ibid., pp.164-165.

${ }^{6}$ Véase Santos Vila, S., El relato fantástico en la literatura occidental durante el siglo XIX: E.T.A. Hoffmann y Ambrose G. Bierce, Tesis doctoral microfilmada, Universidad de Valladolid, Secretariado de Publicaciones e Intercambio Científico de la Universidad de Valladolid, 1999, pp.432-435.
} 
elemento muy apreciado por el autor proveniente de su instrucción topográfica. Se trata del barranco.

A propósito del barranco en la narrativa de Bierce, William Conlogue afirma: "The ravine, a topographical feature well known to Bierce from his work as a topographical engineer in the American Civil War, appears in Bierce's Civil War fiction as a major symbol of death. The ravine plays a significant role in stories where death and infidelity in a love relationship are major themes?

Compartimos con William Conlogue el significado que atribuye al barranco, el cual se desprende del análisis contrastivo de sus cuentos y de las propias preferencias literarias del autor, siendo la muerte uno de los grandes temas que anudan su narrativa breve ${ }^{8}$. No compartimos con Conlogue el que restrinja el alcance simbólico del barranco a los relatos de guerra de Bierce. También sus cuentos fantásticos participan del empleo y significado del símbolo, tal y como pretendemos mostrar.

Cinco son los relatos fantásticos en los cuales aparece el barranco como símbolo. Estos son "The Secret of Macarger's Gulch", "The Night-Doings at "Deadman's" ", "The Stranger", "Present at a Hanging"(The Ways of Ghosts) y "A Man with Two Lives" (Soldier-Folk)9.

"The Secret of Macarger's Gulch" narra cómo Mr. Elderson, un cazador, tiene un sueño premonitorio en conexión con los personajes de una percepción sobrenatural de la que será testigo. Cuando se despierta, escucha en la oscuridad Ios quejidos de una mujer moribunda. Al intentar descubrir el origen del sonido, nada encuentra. Sólo después de unos años conocerá, fortuitamente, que en la cabaña donde tuvo lugar aquella experiencia había ocurrido un crimen tiempo atrás cuyos protagonistas (un matrimonio) eran los de su sueño. En este relato el barranco ya aparece en el título, de tal manera que el autor desde el comienzo nos inicia al contenido de la narración. La huella más clara de su espectro significativo es el asesinato de una mujer, con lo cual la tesis de William Conlogue se

\footnotetext{
${ }^{7}$ Véase Conlogue, W., "A Haunting Memory: Ambrose Bierce and the Ravine of the Dead", Studies in Short Fiction, vol. 28 (1), Winter, 1991, p.21. La negrita es nuestra.

${ }^{8}$ La opinión positiva que Ambrose Bierce tenía de la muerte se refleja, por ejemplo, en una carta dirigida a Mrs. Josephine Clifford McCrackin, fechada el 13 de septiembre de 1913 en Washington, D. C., en la que señala: "Thank you for the book. I thank you for your friendship -and much besides (...) Pray for me? Why, yes, dear -that will not harm either of us. I loathe religions, a Christian gives me qualms and a Catholic sets my teeth on edge, but pray for me just the same, for with all those faults upon your head (it's a nice head, too), I am pretty fond of you, I guess. May you live as long as you want to, and then pass smilingly into the darkness -the good, good darkness". (Véase Pope, B. C. (ed.), op.cit., pp.195-196. La cursiva es nuestra).

${ }^{9}$ Estos relatos aparecieron de manera definitiva en el volumen Can Such Things Be? en la edición de New York, Boni \& Liveright de 1918, y sólo parcialmente en la primera edición de 1893, en New York, Cassell Publishing Co.
} 
confirma con este cuento. El "secreto del barranco de Macarger" es el "secreto de la muerte de Macarger", es decir, de Janet MacGregor ${ }^{10}$.

En "The Night-Doings at “Deadman's" la presencia de lo sobrenatural es por partida doble: por un lado, el fantasma de un chino regresa reiteradamente desde el Más Allá para recuperar su coleta (su seña de identidad), hasta que al fin lo consigue y, en segundo lugar, la Muerte en persona visita al protagonista, Hiram Beeson, para condenarle por no haber querido conceder la coleta al chino11. "Deadman's" (="el Muerto") es el nombre del barranco donde tienen lugar Ios acontecimientos fantásticos, acontecimientos claramente vinculados con la muerte y la penetración personificada de la misma en el mundo de los vivos.

"The Stranger" gira en torno a una figura que se incorpora, de súbito, al fuego de campamento de unos exploradores. Les relata una historia en la que él, Berry Davies, y otros tres compañeros fueron acosados por los indios moradores de aquellos parajes. Tan duro fue el acoso que se vieron obligados a suicidarse. Él ha regresado a informar de lo que les aconteció. Un centinela también vio a tres hombres: el resto de la expedición de Davies. En este cuento además del barranco aparecen otros accidentes del terreno como la cordillera, todos ellos aludiendo a la presencia de la muerte o al encuentro con la misma. El informante Berry Davies comenta en un momento determinado: One morning as we skirted a mountain range, seeking a practicable pass, we were attacked by a band of Apaches who had followed our trail up a gulch - it is not far from here. (p. 48)

En "Present at a Hanging" un ministro baptista, Cummings, presencia la aparición sobrenatural de un vendedor ambulante el cual, tiempo atrás, había sido asesinado en el lugar al que apuntaba su espectro. En el mismo sitio se encontró ahorcado a su supuesto verdugo, Daniel Baker. El barranco vuelve a ser nuevamente el telón de fondo de ambas muertes: "As he (Cummings) came to a little bridge across a dry ravine he saw the figure of a man standing upon it, clearly outlined against the gray background of a misty forest. (...) His attitude had in it a suggestion of abstraction, like that of a sleepwalker. (...) At this the man threw his right hand forward from his side and pointed downward as he stood on the extreme edge of the bridge. Mr. Cummings looked past him, over into the ravine, saw nothing unusual and withdrew his eyes to address the man again. He had disappeared. (...) He (Cummings), (...) early the next morning, accompanied by two neighbors (...) returned to the spot. They found the body of the old man Baker hanging by the neck from one of the beams of the bridge, immediately beneath the spot where the apparition had stood. A thick coating of dust (...) covered the floor of the bridge, but the only footprints were those of $\mathrm{Mr}$.

${ }^{10}$ Macarger es una deformación de MacGregor. Así nos lo hace saber Morgan, un personaje del relato: "...the name of the gulch is a corruption; it should have been called 'MacGregor's' (...)" (p.36)

${ }^{11}$ Se pone de manifiesto en esta narración la preocupación de Bierce por la defensa de la comunidad china, que también se constata en su labor periodística principalmente a través del $\mathrm{Ar}$ gonaut. Los chinos, junto con los negros, eran objeto de la detracción del San Francisco de la época. (Véase Berkove, L. I., Ambrose Bierce's Concern with Mind and Man, Tesis doctoral sin publicar, University of Pennsylvania, 1962, p.67). 
Cummings' horse. In taking down the body the men disturbed the loose, friable earth of the slope below it, disclosing human bones already nearly uncovered by the action of water and frost. They were identified as those of the lost peddler. (p. 133)

Finalmente, "A Man with Two Lives" cuenta la historia de David William Duck, el cual, sin saberlo, está viviendo por segunda vez, después de ser enterrado tras haber sido hallado muerto: su cuerpo estaba mutilado y lleno de balas. El lugar de su "primera muerte" era un barranco, al que Dave Duck había llegado buscando refugio y huyendo de unos indios que le perseguían y hostigaban. Estas son las palabras del propio Duck: I had not gone a hundred yards before I reached the limit of my run -the head of the gulch which I had mistaken for a cañon. It terminated in a concave breast of rock, nearly vertical and destitute of vegetation. In that cul-de-sac I was caught like a bear in a pen. Pursuit was needless; they had only to wait. (p. 394)

En todos los relatos el barranco es el espacio físico donde tiene lugar la muerte de algún o algunos de los personajes. Sólo en "The Secret of Macarger's Gulch" adquiere carta de naturaleza la tesis de William Conlogue, pues el barranco es símbolo de muerte en conexión con una relación amorosa matrimonial, que es el tema principal de la narración. Por otra parte, es evidente que el barranco como símbolo topográfico es un elemento recurrente en los relatos fantásticos de A mbrose Bierce, además de serlo en sus relatos de guerra.

\section{Conclusión.}

En la narrativa breve de Bierce es abundante una simbología de carácter privado que debe mucho a la vida y preferencias del propio autor. El barranco como accidente geográfico es uno de esos símbolos privados que aparece en los cuentos de A mbrose Bierce como motivo muy bien conocido y apreciado por él debido a su instrucción y conocimientos profesionales como ingeniero topógrafo en la Guerra Civil norteamericana. El estudio contrastivo del barranco como símbolo en sus narraciones nos permite afirmar que porta el significado de muerte o bien que es un lugar de muerte. Nos podemos preguntar a qué se debe el origen de tal atribución. Pensamos que la propia identificación del barranco, como término general, con muchos barrancos particulares conocidos por el escritor durante sus años de exploración del territorio americano, escenarios, quizá, de cruentas batallas secesionistas, bien pudo generar esa significación y ese empleo constante en sus numerosos relatos.

\section{Referencias bibliográficas.}

BERKOVE, L.I. Ambrose Bierce's Concern with Mind and Man, Tesis doctoral iné dita, University of Pennsylvania 1962.

BO SSE, D., "From Maps to the Macabre: A mbrose Bierce as Topographer", Geography and Map Division Bulletin, SLA. 144, June, 1986, pp.2-15. 
CONLOGUE, W. "A Haunting Memory: Ambrose Bierce and the Ravine of the Dead", Studies in Short Fiction, vol. 28 (1), Winter, 1991, pp.21-29.

H O PKIN S, E.J. (comp.), The Complete Short Stories of Ambrose Bierce, Lincoln and London (University of Nebraska Press) 1984.

M cWILLIA M S, C. Ambrose Bierce. A Biography, Archon Books 1967.

POPE, B.C. (ed.), The Letters of Ambrose Bierce, N ew York (Gordian Press) 1967.

SANTOS VILA, S. El relato fantástico en la literatura occidental durante el siglo XIX: E.T.A. Hoffmann y Ambrose G. Bierce, Tesis doctoral microfilmada, Secretariado de Publicaciones e Intercambio Científico de la Universidad de VaIladolid, 1999. 